Marquette University

e-Publications@Marquette

Biological Sciences Faculty Research and

Publications

Biological Sciences, Department of

$1-1-2008$

Effect of Ethanol on Microbial Community

Structure and Function During Natural

Attenuation of Benzene, Toluene, and $o$-Xylene in a Sulfate-reducing Aquifer

Kevin Feris

Boise State University

Doug Mackay

University of California - Davis

Nick de Sieyes

Stanford University

Irina Chakraborty

University of California - Davis

Murray Einarson

Geomatrix Consultants

See next page for additional authors

Accepted version. Environmental Science \& Technology, Vol. 42, No. 7 (2008): 2289-2294. DOI. (C) 2008 American Chemical Society. Used with permission.

Krassimira Hristova was affiliated with the University of California - Davis at the time of publication. 
Authors

Kevin Feris, Doug Mackay, Nick de Sieyes, Irina Chakraborty, Murray Einarson, Krassimira R. Hristova, and Kate M. Scow 


\title{
Effect of Ethanol on Microbial Community Structure and Function During Natural Attenuation of Benzene, Toluene, and $o$-Xylene in a Sulfate-reducing Aquifer
}

\author{
Kevin Feris \\ Department of Biology, Boise State University, \\ Boise, ID \\ Doug Mackay \\ Department of Land, Air \& Water Resources, \\ University of California, \\ Davis, $C A$ \\ Nick de Sieyes \\ Department of Environmental Engineering, Stanford University, \\ Palo Alto, $C A$ \\ Irina Chakraborty \\ Department of Land, Air \& Water Resources, \\ University of California, \\ Davis, $C A$
}




\author{
Murray Einarson \\ Geomatrix Consultants, \\ Oakland, $C A$ \\ Krassimira Hristova \\ Department of Land, Air \& Water Resources, \\ University of California, \\ Davis, $C A$ \\ Kate Scow \\ Department of Land, Air \& Water Resources, \\ University of California, \\ Davis, $C A$
}

\title{
Synopsis
}

In a continuous release field experiment, ethanol altered microbial community structure/function, lowered the redox state, and slowed biodegradation of coreleased BTo-X in an anaerobic aquifer.

\section{Abstract}

Ethanol $(\mathrm{EtOH})$ is a commonly used fuel oxygenate in reformulated gasoline and is an alternative fuel and fuel supplement. Effects of EtOH release on aquifer microbial ecology and geochemistry have not been well characterized in situ. We performed a controlled field release of petroleum constituents (benzene (B), toluene $(T), o-x y l e n e(o-X)$ at $\sim 1-3 \mathrm{mg} / \mathrm{L}$ each) with and without $\mathrm{EtOH}(\sim 500 \mathrm{mg} / \mathrm{L})$. Mixed linear modeling (MLM) assessed effects on the microbial ecology of a naturally sulfidic aquifer and how the microbial community affected $\mathrm{B}, \mathrm{T}$, and $\mathrm{o}-\mathrm{X}$ plume lengths and aquifer geochemistry. Changes in microbial community structure were determined by quantitative polymerase chain reaction (qPCR) targeting Bacteria, Archaea, and sulfate reducing bacteria (SRB); SRB were enumerated using a novel qPCR method targeting the adenosine-5'-phosphosulfate reductase gene. Bacterial and SRB densities increased with and without EtOH-amendment (1-8 orders of magnitude). Significant increases in Archaeal species richness; Archaeal cell densities (3-6 orders of magnitude); B, T, and $o-X$ plume lengths; depletion of sulfate; and induction of methanogenic conditions were only observed with EtOH-amendment. MLM supported the conclusion that EtOH-amendment altered microbial community structure and function, which in turn lowered the 
aquifer redox state and led to a reduction in bioattenuation rates of $\mathrm{B}, \mathrm{T}$, and $O-X$.

\section{Introduction}

Ethanol is rapidly replacing methyl tert-butyl ether (MTBE) as the most commonly used fuel oxygenate in reformulated gasoline and is used as an alternative fuel and fuel supplement. Ethanol is a highly labile substrate that can be metabolized by a wide array of microorganisms under aerobic and anaerobic conditions. For this reason, ethanol has largely been assumed to be an innocuous replacement for MTBE. However, the introduction of labile carbon into carbon-limited subsurface environments (e.g., before or long after spills of gasoline) or electron donors (e.g., as in the case of many MTBE plumes) can dramatically change prevailing redox conditions and can alter the structure and function of subsurface microbial communities. ${ }^{1,2}$ Functional changes may include preferential degradation of more labile carbon substrates over other biodegradable and more toxic compounds present (e.g., benzene (B), toluene ( $T$ ), xylene $(X)$, and ethylbenzene $(E)) \cdot{ }^{3}$ A growing body of work has examined the influence of ethanol on the natural attenuation and biodegradation of BTEX under both aerobic and anaerobic conditions ${ }^{4-8}$ These studies suggest that simultaneous introduction of ethanol and BTEX will result in decreased BTEX attenuation rates and longer contaminant plumes. The majority of previous results, however, are based on microcosm or column experiments ${ }^{4,5,8}$ or on small sets of observational field data comparing contaminated aquifers exposed or not exposed to ethanol. ${ }^{9}$

We conducted a side-by-side field experiment to determine if ethanol release impacts BTEX attenuation and microbial community composition in a complex aquifer environment. This is the third in a series of papers reporting results from a comprehensive field study investigating the influence of ethanol on attenuation of selected BTEX species in a sulfate-dominated anaerobic aquifer. The first two publications address experimental setup, site conditions, and results of monitoring impacts of ethanol on the fate of selected BTEX species and MTBE in situ. ${ }^{3,10}$ This study describes how the release of $B, T$, and oxylene $(o-X)$ or $\mathrm{B}, \mathrm{T}, \mathrm{o}-\mathrm{X}$, and ethanol affects the structure and function of aquifer microbial communities and, to the best of our

Environmental Science \& Technology, Vol 42, No. 7 (2008): pg. 2289-2294. DOI. This article is (C) American Chemical Society and permission has been granted for this version to appear in e-Publications@Marquette. American Chemical Society does not grant permission for this article to be further copied/distributed or hosted elsewhere without the express permission from American Chemical Society. 
knowledge, is the first to link quantitative changes in microbial communities with the natural attenuation of $\mathrm{B}, \mathrm{T}$, and $\mathrm{o}-\mathrm{X}$ and changes in subsurface aquifer geochemistry in situ.

\section{Experimental Section}

\section{Site Description}

Our study site was a shallow coastal alluvial aquifer at Site 60 on Vandenberg Air Force Base (VAFB), California. Approximately 750 gallons of MTBE-laden fuel was released into the subsurface in $1995 .{ }^{11}$ Whether there were earlier releases of fuel is unknown. University of Waterloo and UC Davis have been conducting research here since 1999; thus, many of the hydrogeological and geochemical aspects of the field site have been described. ${ }^{2,11-16}$ Table S.1 of the Supporting Information indicates the predominant pre-experiment geological, hydrological, and geochemical conditions. Groundwater flow rates averaged $0.3-0.6 \mathrm{~m} \cdot \mathrm{day}^{-1}$. The monitoring network addressed in this paper consisted of 192 discrete sampling points within a $515 \mathrm{~m}^{2}$ study area, arranged in a series of transects perpendicular to flow within a thin, shallow, relatively continuous aquifer called the S3 sand (Figure 1). General hydrogeology and well construction is described elsewhere. ${ }^{3}$ Wells were placed in close proximity to enable highresolution characterization of the subsurface (1-3 ft between wells). A persistent relatively continuous MTBE plume appears to originate from higher concentrations of contaminants remaining in a shallower, less permeable, and horizontally restricted layer. 


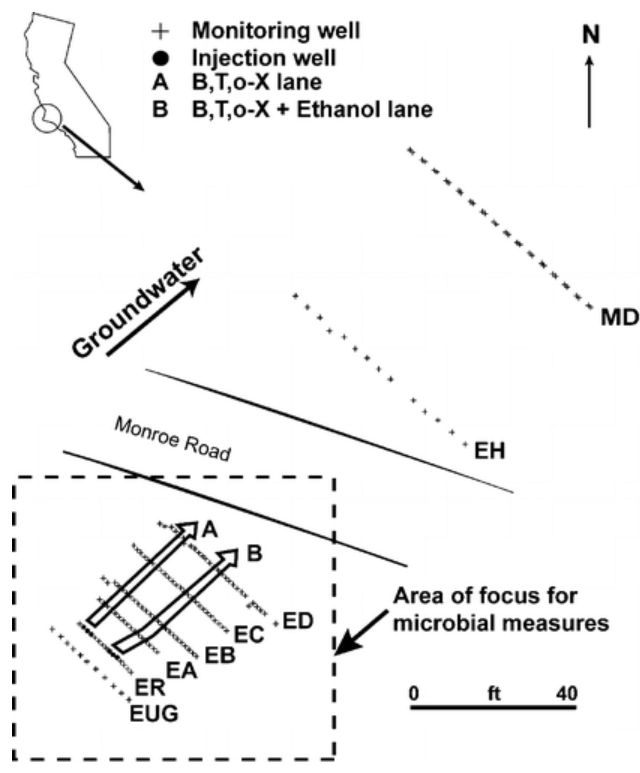

Figure 1. Location of VAFB Site 60 , general layout of groundwater-monitoring well network, and direction of groundwater flow. EUG, ER, EA, etc. delineate monitoring well transects.

Experimental Injection of $\mathrm{B}, \mathrm{T}, \mathrm{o}-\mathrm{X}$, with and without Ethanol Two side-by-side concurrent treatments were applied to the S3 sand. Three "no ethanol" wells received anaerobic site groundwater amended with $\mathrm{B}, \mathrm{T}, \mathrm{o}-\mathrm{X}$, and tracers; the three "with ethanol" wells ( $3 \mathrm{ft}$ away along the same transect) received anaerobic site groundwater amended with the same concentrations of $B, T, o-X$, and tracers, with the addition of ethanol. Concentrations of injected $B, T, o-X$, and ethanol were relatively consistent over the course of the experiment in both lanes (mean \pm standard error $(\mathrm{mg} / \mathrm{L}$ ): benzene $=2.3 \pm 0.6$, toluene $=2.2 \pm 1.0, o$-xylene $=0.865 \pm 0.36$, ethanol (With Ethanol Lane only) $=470 \pm 220$ ). Experimental amendments started on May 13,2004 (day 0 ) and continued for a total duration of $\sim 9$ months, with relatively continuous injection only for the last 7 months due to system refinements and regular maintenance. For a more in-depth description of the injection system see Mackay et al. ${ }^{3}$

\section{Groundwater Analyses}

Volatile organic compounds (VOCs, e.g. B, T, o-X, MTBE, and ethanol), dissolved methane, sulfate, $\mathrm{pH}$, ferrous iron, and sulfide levels were measured as described elsewhere. ${ }^{3}$ Detection limits for these compounds were $<0.010 \mathrm{mg} / \mathrm{L}$ for $\mathrm{B}, \mathrm{T}, \mathrm{o}-\mathrm{X}$, and MTBE, 
approximately $1.250 \mathrm{mg} / \mathrm{L}$ for EtOH, approximately $0.250 \mathrm{mg} / \mathrm{L}$ for methane, $1 \mathrm{mg} / \mathrm{L}$ for sulfate, $0.02 \mathrm{mg} / \mathrm{L}$ for ferrous iron, and 0.005 $\mathrm{mg} / \mathrm{L}$ for sulfide. An in-depth analysis of the aquifer geochemistry was performed after 5 months of continuous release (Figures 3 and S.1 and Mackay et al. $)^{3}$

\section{Water Sample Collection and DNA Extraction for Microbial Analyses}

Water samples $(500 \mathrm{~mL})$ were collected in sterile plastic bottles from 127 monitoring wells at three time points: prior to the experiment and after 5 and 8 months of continuous release using a peristaltic pump drawing at $300 \mathrm{~mL} \cdot \mathrm{min}^{-1}$; each well was purged for 1 min prior to sample collection. Samples were stored on ice and were filtered through $0.2 \mu \mathrm{m}$ Isopore membrane filters (Millipore, Bedford, Massachusetts) within $48 \mathrm{~h}$ of sample collection to collect and concentrate cells on the filters. DNA was extracted from the filters as previously described. ${ }^{17}$ Samples requiring more than one $0.2 \mu \mathrm{m}$ filter to process the entire $500 \mathrm{~mL}$ sample were extracted separately and were pooled prior to quantitative polymerase chain reaction (qPCR) analyses.

\section{Quantitative PCR}

Quantitative PCR ( $q P C R$ ) was employed to enumerate relative abundance of all Bacteria and Archaea (based on 16S rDNA copy numbers) and sulfate reducing bacteria (SRB, based on adenosine-5'phosphosulfate reductase genes (aps)) within each groundwater sample. qPCR reactions were performed with an ABI Prism 7300 (Applied Biosystems, Foster City, California) and either a Taqman or SYBR Green I detection method. qPCR reactions enumerating total Bacteria ${ }^{18}$ and Archaea ${ }^{19}$ were performed as previously described. SRB were enumerated by a novel aps qPCR system developed here. Primers designed for the aps qPCR assay were site-specific, that is, generated by analysis of aps gene sequences recovered from the Site 60 aquifer. Two novel PCR primers, APS328f and APS743r, were designed to amplify a 415bp portion of the aps gene (Supporting Information) and were used to develop a SYBR GreenI SRB quantification system (Supporting Information). Initial measures of the 
gene associated with anaerobic toluene degradation (bssA) (5 month time point) suggested that bssA copy numbers were very low or below detection in most samples; therefore, this measure was not pursued further (data not shown). To avoid problematic conversion of gene detection frequencies to cells per/ml for uncultured organisms, abundance values for each qPCR system are reported as copy numbers/ml of groundwater (Supporting Information).

\section{Statistical Analyses}

Microbial abundance data and geochemical parameters (dissolved $\mathrm{SO}_{4}{ }^{2-}$ and $\mathrm{CH}_{4}$ ) were analyzed with a series of mixed linear models (MLM) using sampling date and well location as repeated and subject variables, respectively. The MLM approach allowed us to test for relationships between the applied treatments of BTX (no ethanol) and BTX with ethanol and the response variables-microbial abundance and dissolved $\mathrm{SO}_{4}{ }^{2-}$ and $\mathrm{CH}_{4}$-while simultaneously accounting for dependence of each response variable measured at each location and time on the previous sample set (i.e., responses measured after 8 months were inherently dependent on responses at 5 months). For additional detail on MLM analyses see the Supporting Information. All statistical tests were performed using SPSS v11.0.4 software (SPSS Inc., Chicago, Illinois), and $p$-values of 0.05 or less were considered indicative of significant interactions.

\section{Results}

\section{VOC Distributions in Groundwater}

Location of injection wells, expected flow directions, and applied treatment combinations are indicated in Figure 1. Injection of amended groundwater produced two distinctly different zones within the aquifer. Figure 2 presents part of the evidence, that is, the distributions of dissolved BTo-X expressed as total volatile organic carbon (VOC) 5 and 8 months after the start of injection (detailed descriptions of geochemical changes and impacts on $\mathrm{B}, \mathrm{T}$, and $\mathrm{o}-\mathrm{X}$ plume lengths are reported elsewhere). ${ }^{3}$ Ethanol was detected in groundwater $1.5 \mathrm{ft}$ from the with ethanol lane release wells at only two time points, 1 and 2 days after the start of injection at 480 and 780 
ppb, respectively, and thus is not depicted in the figure. The rapid loss of ethanol in the aquifer was likely due to rapid consumption by native microorganisms. The length of $\mathrm{B}, \mathrm{T}$, and $\mathrm{o}-\mathrm{X}$ plumes in treatment lanes with and without ethanol were distinctly different for the duration of the experiment, ${ }^{3}$ as shown in Figure 2 . After 4 and 8 months of injection, total VOC plumes were significantly longer in the With Ethanol Lane than the Without Ethanol Lane; plumes retracted in both lanes as the experiment proceeded (Figure 2).
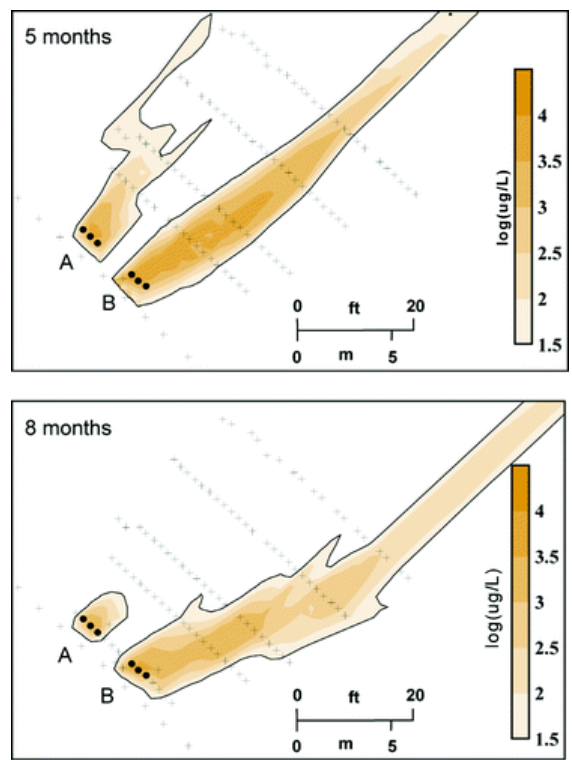

Figure 2. Total volatile organic carbon (i.e., benzene, toluene, and $o$-xylene) plumes after 5 and 8 months of continuous injection. (A) B, T, and o-X (no ethanol lane) and (B) $B, T, O-X$, and ethanol (with ethanol lane). Black contour lines on figures represent threshold values for total VOC that are above $15 \mu \mathrm{g} / \mathrm{L}$.

\section{Microbial Community and Geochemical Response}

Relationships between microbial densities and total VOC with and without ethanol treatments were assessed via MLM, and the significance of these relationships are presented as $p$-values. Subsequent MLMs were used to evaluate relationships between microbial densities and changes in geochemical parameters (Figures 3 and 4 and Table 1). Analysis of up-gradient samples and betweentreatment "lane" samples acted as in-field controls, thereby allowing us to compare treatment effects relative to background conditions. Regions of the aquifer unaffected by the release supported an average of $2.8 \times 10^{4} \pm 4.2 \times 10^{3}$ Bacterial $16 \mathrm{~S}$ copies/ml (mean \pm standard 
NOT THE PUBLISHED VERSION; this is the author's final, peer-reviewed manuscript. The published version may be accessed by following the link in the citation at the bottom of the page.

deviation), $1.4 \times 10^{3} \pm 1.8 \times 10^{2}$ Archaeal $16 \mathrm{~S}$ copies $/ \mathrm{ml}$, and $1.7 \times$ $10^{2} \pm 1.8 \times 10^{1}$ aps copies $/ \mathrm{ml}$. A small zone of elevated Bacterial and SRB densities at the west end of the EB transect, detected at 8 months outside of the Without Ethanol Lane, was apparently correlated with a low-concentration toluene plume from a source other than our controlled injections.
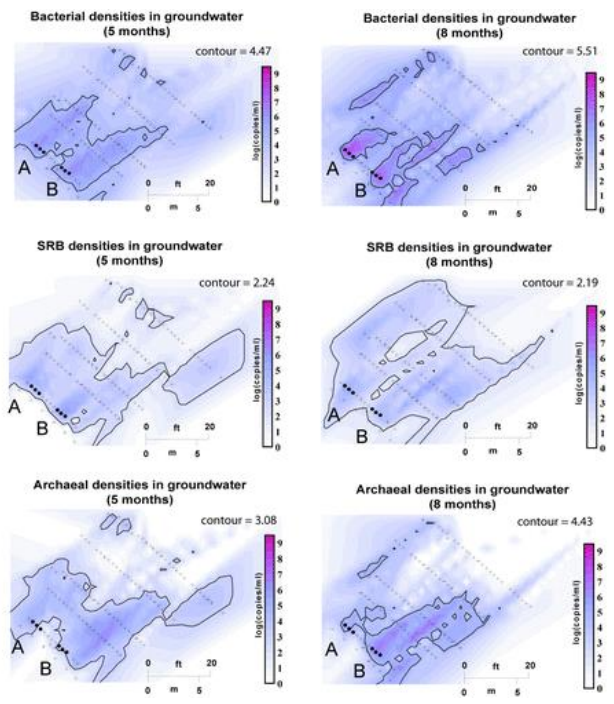

Figure 3. Distribution of microorganisms within the aquifer. (A) $B, T$, and $o-X$ (no ethanol lane) and (B) B, T, o-X, and ethanol (with ethanol lane). Black contour lines on figures represent threshold values for each measured group that are above background levels, as determined by microbial densities in wells up-gradient of the experiment for each group, at the respective time points.
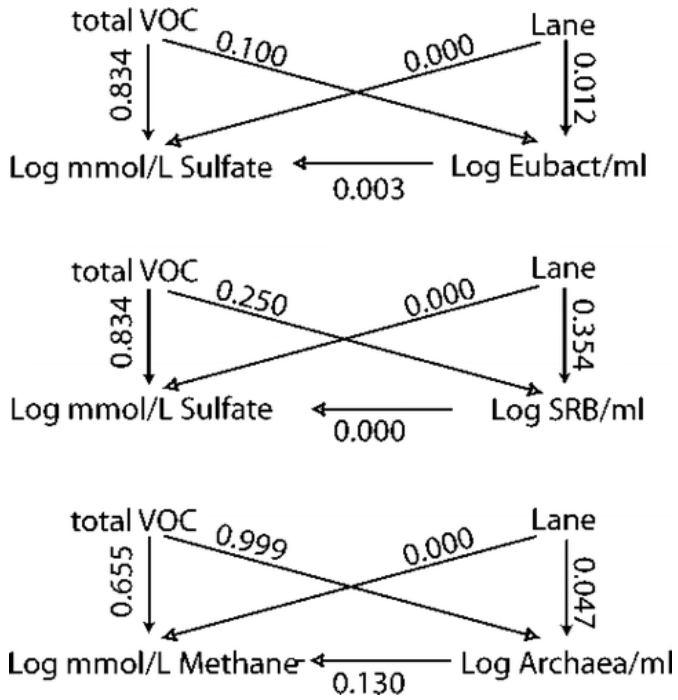

Figure 4. MLM of interactions of total VOC and presence of ethanol (i.e., Lane) on microbial densities and dissolved geochemical markers (i.e., $\mathrm{SO}_{4}{ }^{2-}$ and $\mathrm{CH}_{4}$ ) and corresponding influence of microbial densities on dissolved geochemical markers.

Environmental Science \& Technology, Vol 42, No. 7 (2008): pg. 2289-2294. DOI. This article is (C) American Chemical Society and permission has been granted for this version to appear in e-Publications@Marquette. American Chemical Society does not grant permission for this article to be further copied/distributed or hosted elsewhere without the express permission from American Chemical Society. 
NOT THE PUBLISHED VERSION; this is the author's final, peer-reviewed manuscript. The published version may be accessed by following the link in the citation at the bottom of the page.

Direct effects between factors are indicated by arrows (predictor variables: beginning of arrow; response variables: end of arrow). The significance ( $p$-value) of each direct effect is indicated by the number on the arrow.

Table 1. MLM Model Results (i.e., $p$-Values) Testing Effects of Different Microbial Groups on Selected Geochemical Variables ${ }^{a}$

\begin{tabular}{|c|c|c|c|c|c|c|c|}
\hline \multirow[b]{2}{*}{$\begin{array}{c}\text { well } \\
\text { transect }\end{array}$} & \multirow[b]{2}{*}{$\begin{array}{l}\text { distance from } \\
\text { release wells } \\
\text { (m) }\end{array}$} & \multicolumn{2}{|c|}{$\begin{array}{c}\text { log eubact as } X, \log \\
\text { sulfate as } Y\end{array}$} & \multicolumn{2}{|c|}{$\begin{array}{c}\log \text { SRB as } X, \log \\
\text { sulfate as } Y\end{array}$} & \multicolumn{2}{|c|}{$\begin{array}{c}\text { log Archaea as } X, \log \\
\text { methane as } Y\end{array}$} \\
\hline & & $\begin{array}{c}\text { no } \\
\text { ethanol }\end{array}$ & $\begin{array}{c}\text { with } \\
\text { ethanol }\end{array}$ & $\begin{array}{c}\text { no } \\
\text { ethanol }\end{array}$ & $\begin{array}{c}\text { with } \\
\text { ethanol }\end{array}$ & $\begin{array}{c}\text { no } \\
\text { ethanol }\end{array}$ & $\begin{array}{c}\text { with } \\
\text { ethanol }\end{array}$ \\
\hline ER & 0 & $<0.001$ & $<0.001$ & $<0.001$ & $<0.001$ & 0.242 & $<0.001$ \\
\hline EA & 5 & 0.586 & $<0.001$ & 0.837 & $<0.001$ & 0.671 & $<0.001$ \\
\hline EB & 7 & 0.645 & $<0.001$ & 0.721 & $<0.001$ & 0.275 & $<0.001$ \\
\hline$=C$ & 10 & 0.763 & 0.001 & 0.866 & $<0.001$ & 0.371 & $<0.001$ \\
\hline$E D$ & 15 & 0.363 & $<0.001$ & 0.574 & $<0.001$ & 0.509 & 0.017 \\
\hline
\end{tabular}

aAnalyses were performed using experimental lane (e.g., no ethanol vs with ethanol) and monitoring well transects (e.g., ER, EA, etc.) as fixed variables. Model results indicate locations where significant relationships exist between microbial predictor variables $(X)$ and geochemical response variables $(Y)$.

\section{Total Bacteria}

Bacterial densities were significantly higher in the experimental lanes relative to background levels ( $1-8$ orders of magnitude) ( $p=$ $0.043)$. The presence of $B, T$, and $o-X$ was significantly related to Bacterial densities only in the Without Ethanol Lane $(p=0.057)$. Bacterial densities were highest closest to the release wells and decreased down-gradient (Figure 3). There was a significantly greater down-gradient distribution of Bacteria in the With Ethanol Lane than the Without Ethanol Lane $(p=0.022)$. Elevated densities of Bacteria extended at least as far as the ED transect in the With Ethanol Lane ( $p$ $=0.009$ ) and only as far as the EC in the Without Ethanol Lane ( $p=$ 0.017). Increases in Bacteria in the Without Ethanol Lane correlated with a greater retraction of the $\mathrm{B}, \mathrm{T}$, and $\mathrm{o}-\mathrm{X}$ plumes (total VOC) than those observed in the With Ethanol Lane by 8 months (Figures 2 and 3).

Before the experiment began, sulfate reduction was presumed to be the dominant redox process because of the presence of high sulfate concentrations and an absence of significant sources $\mathrm{Of}^{\mathrm{NO}_{3}{ }^{-} \text {or }}$ soluble $\mathrm{Fe}^{3+}$ in the aquifer. Previous microcosm and site characterization studies indicated that iron-reducing bacteria make up

Environmental Science \& Technology, Vol 42, No. 7 (2008): pg. 2289-2294. DOI. This article is (C) American Chemical Society and permission has been granted for this version to appear in e-Publications@Marquette. American Chemical Society does not grant permission for this article to be further copied/distributed or hosted elsewhere without the express permission from American Chemical Society. 
NOT THE PUBLISHED VERSION; this is the author's final, peer-reviewed manuscript. The published version may be accessed by following the link in the citation at the bottom of the page.

a small portion of the aquifer microbial community. Therefore, observed increases in total Bacteria were likely due to stimulation of SRB and fermentative bacteria.

\section{Sulfate Reducing Bacteria}

SRB as a fraction of total Bacteria decreased over time in both lanes. SRB made up $26 \pm 13 \%$ and $0.1 \pm 0.01 \%$ of total Bacteria in the Without Ethanol Lane and $51.5 \pm 27 \%$ and $0.14 \pm 0.03 \%$ of Bacteria in the With Ethanol Lane in samples taken from release wells at 5 and 8 months, respectively. When data from each time point was considered independently, SRB densities were significantly elevated in the With and Without Ethanol Lanes relative to background ( $p=$ 0.022 ), and levels of SRB were greater in the With Ethanol Lane than the Without Ethanol Lane $(p=0.001)$. The distribution of SRB in the direction of groundwater flow significantly changed $(p=0.001)$ in both lanes. At 5 months, the highest proportion of SRB was observed in the ER transect, whereas at 8 months the highest proportion of SRB was observed down-gradient in the EA, EB, EC, and ED transects to the east side of the With Ethanol Lane $(36.5,17.7,8.9$, and $8 \%$ of total Bacterial densities, respectively) (Figure 3). Changes in SRB densities and distributions were strongly related to concentrations of sulfate in the experimental lanes.

Sulfate levels were measured in all monitoring wells after 5 months of continuous injection (Figure S.1, Supporting Information) and were significantly depleted in the With Ethanol Lane relative to the Without Ethanol Lane and were related to densities of Bacteria and SRB $(p<0.001)$. This relationship was evident at a greater distance down-gradient in the With Ethanol Lane, extending to the EB and through the ED transects for SRB and Bacteria, respectively (Table 1). Sulfate depletion in the With Ethanol Lane extended approximately $200 \mathrm{ft}$ down-gradient from the ethanol injection site. There was a small decrease in dissolved sulfate $(10-30 \mathrm{mg} / \mathrm{L})$ in the Without Ethanol Lane relative to background sulfate concentrations; however, this decrease was within the range of variation observed in monitoring wells outside the experimental treatment zones $(30-50 \mathrm{mg} / \mathrm{L}$ ) (Figure S.1, Supporting Information). A significant relationship between Bacterial and SRB densities in the Without Ethanol Lane was only 
observed in the ER transect (Table 1). Therefore the electron donor concentration in the Without Ethanol Lane was too low to significantly affect the redox state and microbial communities in the aquifer except very near the injection wells.

The relative abundance of SRB decreased during the experiment; this observation may be explained by the amount of labile carbon released in the With Ethanol Lane. The concentration of ethanol released ( $\sim 500 \mathrm{ppm})$ was approximately 10 times greater than could be consumed by sulfate reduction alone, based on average groundwater sulfate content $(\sim 160 \mathrm{ppm})$. Initial increases in SRB and corresponding depletion of sulfate indicates that ethanol release stimulated SRB metabolism and cellular growth, resulting in complete consumption of available sulfate in the injected water. The SRB bloom was analogous to the increase in iron reducing bacteria, followed by an increase in SRB upon injection of acetate to another anaerobic aquifer. ${ }^{20}$ In our system, sulfate was slowly replenished into the experimental lanes via the injected water and by lateral dispersion from surrounding sulfate-rich groundwater; thus, the bloom in SRB produced in response to the ethanol release was self-limiting, being dependent on a rapidly consumed yet limited supply of dissolved sulfate. As the sulfate-depleted zone expanded up-gradient to include the release wells (as suggested by $\mathrm{CH}_{4}$ distribution in Figure S.1, Supporting Information), the sulfate-reducing region and area of elevated SRB densities shifted down-gradient (Figure 3).

\section{Archaea}

The distribution of Archaea was significantly related to the presence of ethanol ( $p=0.047$ ) (Figures 3 and 4). In the With Ethanol Lane, Archaea were elevated above background up to the EB transect $(p=0.006)$ after 5 months of continuous injection and expanded to include the ER through EC transects after 8 months. Maximum observed Archaeal densities were 3-6 orders of magnitude above background and were located in the ER wells at 8 months $\left(9.5 \times 10^{6}\right.$ Archaeal $16 \mathrm{~S}$ rDNA copies/mL). Elevated Archaea were only observed in the With Ethanol Lane where sulfate was depleted (Figure 3). Increased Archaeal densities were likely due to the acetogenic 
fermentation of ethanol, providing an ample supply of acetate for Archaeal growth.

The highest Archaeal densities correlated with the region exhibiting active methane production (Figure S.3, Supporting Information). Increases in Archaeal densities in sulfate-depleted zones accompanied development of an active methanogenic zone with methane concentrations up to $16.4 \mathrm{mg} / \mathrm{L}$ after 5 months of injection (Figure S.1, Supporting Information) and increasing to near saturation (max $37.8 \mathrm{mg} / \mathrm{L}$ ) after 8 months (Figures S.1 and 3). Significant interactions between Archaea and $\mathrm{CH}_{4}$ were present in both lanes in the EA transect $(p<0.05)$; however, only in the With Ethanol Lane was there a significant trend between Archaea and $\mathrm{CH}_{4}$ in downgradient transects (EB through ED) $(0.05<p<0.10)$ (Table 1 ). Calculations of methane mass discharge in the With Ethanol Lane suggest active methane production at least $6 \mathrm{~m}$ down-gradient from the injection wells (i.e., EB transect), an observation that fits well with the observed increase in Archaeal densities in this lane (Figure S.3, Supporting Information). Thus, the release of ethanol appeared to stimulate growth of native methanogenic populations and to established a large methanogenic zone in the With Ethanol Lane.

\section{Fermenters}

Bacteria other than SRB were stimulated by the controlled release. SRB made up 51 and $26 \%$ of the elevated Bacterial biomass in lanes with and without ethanol, respectively. Apparently, stimulation of the Archaeal/methanogenic community was accompanied by an increase in fermentative bacteria and in fermentative metabolism. This hypothesis is supported by the presence of small plumes of propionate and acetate (two metabolic products of fermentation) in the With Ethanol Lane down-gradient from the release wells after 5 months of continuous release (Figure S.2, Supporting Information). Presence of these organic acids indicates that some non-SRB microorganisms detected by Bacterial qPCR were fermentative bacteria (e.g., acetogens, etc.). Elevated Archaeal densities co-occurred with methane production both within and down-gradient of wells in which we detected propionate and acetate (Figures S.1 and S.2, Supporting Information). Although propionate and acetate were not measured at 8 
months, high concentrations of methane at this time point suggest these organic acids were being produced and rapidly consumed by in situ fermentative/methanogenic consortia and likely existed for much of the experiment. The co-occurrence of SRB and fermentative/methanogenic consortia is likely due to subsurface heterogeneity creating spatially and temporally variable redox conditions that prevent competitive exclusion of either metabolic group. Other studies have observed the co-occurrence of these metabolic groups. ${ }^{21,22}$

Additional observations support the hypothesis that with the change in geochemical conditions the community composition shifted toward one dominated by fermentative/methanogenic consortia in the With Ethanol Lane. During the experiment, the water levels in the With Ethanol Lane injection wells would periodically increase and would lead to the threat of, or actual, brief overflowing. This necessitated frequent well development to maintain constant long-term injection rates. This reduced permeability was apparently due to the 100 -fold increase in microbial biomass (Figure 3 ) and/or sulfide mineral precipitation resulting from sulfate reduction around the release wells. A reduction in permeability around the With Ethanol injection wells could presumably have increased the width of the injection zone and consequently the zone within which sulfate was depleted, thereby facilitating the ability of fermentative/methanogenic consortia to outcompete a more energetically favorable SRB-dominated microbial community. Changes in spatial distribution of SRB, Bacteria, and Archaea between 5 and 8 month samplings support this hypothesis. The shift to a fermentative/methanogenic community would result in reduced attenuation rates of $\mathrm{B}, \mathrm{T}$, and $\mathrm{o}-\mathrm{X}$.

\section{Discussion}

Concentrations of ethanol added in our experiment, which were intended to represent groundwater impacts of small-volume releases of E10 gasohol (gasoline containing $10 \%$ ethanol), were large enough to promote substantial microbial growth in the release zone and to trigger a cascade of biogeochemical changes leading to selection and restructuring of the local microbial community. Effects on microbial communities would likely be even greater with higher concentrations 
of ethanol (e.g., as in biofuels where ethanol may constitute up to $\sim 85 \%$ of the volume). Observed increases in Bacterial and Archaeal densities and attenuation of ethanol, B, T, and $o-X$ are consistent with the conclusions of Mackay et al. ${ }^{3}$ that losses of these compounds are due to active microbial biodegradation and not other physical processes (e.g., sorption and dispersion). Reduced BTEX attenuation rates under methanogenic vs sulfate reducing conditions have been observed in multiple field and laboratory studies. ${ }^{23,24}$ Rate differences may be due to additional energy conserved during complete oxidation of BTEX to $\mathrm{CO}_{2}$ when sulfate is used as the terminal electron acceptor compared to oxidation under methanogenic conditions where a combination of fermentation and $\mathrm{CO}_{2}$ reduction is involved. Previous laboratory and observational field studies have demonstrated similar trends of reduced $\mathrm{B}, \mathrm{T}$, and $\mathrm{o}-\mathrm{X}$ degradation rates in the presence of ethanol. ${ }^{9}$ Other groups have found similar trends in column studies assessing influences of ethanol on BTEX attenuation under a variety of redox conditions. ${ }^{24}$ Our observations add to the mounting evidence and provide the first controlled, field-based experimental evidence that the release of ethanol can negatively impact bioattenuation of BTEX under anaerobic conditions.

Further, the methanogenic conditions induced by the ethanol release may have effects beyond increased BTX plume lengths. For example, in locations with existing MTBE contamination, a likely characteristic of sites with potential for unintended subsurface gasoline release, active methanogenic conditions may result in increased rates of conversion of MTBE to tert-butyl alcohol (TBA). ${ }^{10,25}$ Based on our work, additional studies examining the influence of ethanol release on other subsurface contaminants (e.g., 1,2-dichloroethane dichloride or ethylene dibromide, both previously used in gasolines) ${ }^{26}$ may be warranted.

\section{Acknowledgment}

This research was supported by National Institute of Environmental Health Sciences (NIEHS) grant No. 5 P42 ES04699-16 (i.e., National Institute of Health (NIH) with funding provided by U.S. Environmental Protection Agency (EPA)). Its contents are solely the responsibility of the authors and do not necessarily represent the official views of the NIEHS, NIH, or EPA. Additional support was provided by the National Science Foundation Microbial 
NOT THE PUBLISHED VERSION; this is the author's final, peer-reviewed manuscript. The published version may be accessed by following the link in the citation at the bottom of the page.

Observatories program. Support for field experiments was provided primarily by the California Department of Health Services via Contract No. 01-16433 $(\$ 1,149,684)$ and the American Petroleum Institute.

\section{Supporting Information}

Additional information on site characteristics, geochemistry, fermentation product formation, and methane mass discharge. This information is available free of charge via the Internet at http://pubs.acs.org.

\section{References}

${ }^{1}$ Schreiber, M. E.; Carey, G. R.; Feinstein, D. T.; Bahr, J. M. Mechanisms of electron acceptor utilization: Implications for simulating anaerobic biodegradation J. of Contamin. Hydrol. 200473 1-4 99127

${ }^{2}$ Feris, K. P.; Hristova, K.; Grebreyesus, B.; Mackay, D.; Scow, K. M. A shallow BTEX and MTBE contaminated aquifer supports a diverse microbial community Microb. Ecol. 2004484589600

${ }^{3}$ Mackay, D.; de Sieyes, N.; Einarson, M.; Feris, K. P.; Pappas, A.; Wood, I. A.; Jacobson, L.; Justice, L. G.; Noske, M. N.; Scow, K.; Wilson, J. T. Impact of ethanol on the natural attenuation of benzene, toluene, and $o$-xylene in a normally sulfate-reducing aquifer Environ. Sci. Technol. 2006401961236130

${ }^{4}$ Da Silva, M. L. B.; Alvarez, P. J. J. Effects of ethanol versus mtbe on benzene, toluene, ethylbenzene, and xylene natural attenuation in aquifer columns J. Environ. Eng., ASCE 20021289862867

${ }^{5}$ Ruiz-Aguilar, G. M. L.; Fernandez-Sanchez, J. M.; Kane, S. R.; Kim, D.; Alvarez, P. J. J. Effect of ethanol and methyl-tert-butyl ether on monoaromatic hydrocarbon biodegradation: Response variability for different aquifer materials under various electron-accepting conditions Environ. Toxicol. Chem. 2002211226312639

${ }^{6}$ Lovanh, N.; Hunt, C. S.; Alvarez, P. J. J. Effect of ethanol on BTEX biodegradation kinetics: Aerobic continuous culture experiments Wat. Res. 2002361537393746

${ }^{7}$ Beller, H.; Kane, S.; Legler, T.; Alvarez, P. A real-time polymerase chain reaction method for monitoring anaerobic, hydrotarbon-degrading bacteria based on a catabolic gene Environ. Sci. Technol. 20023618 39773984

${ }^{8}$ Corseuil, H. X.; Hunt, C. S.; Dos Santos, R. C. F.; Alvarez, P. J. J. The influence of the gasoline oxygenate ethanol on aerobic and anaerobic BTX biodegradation Wat. Res. 199832720652072

${ }^{9}$ Ruiz-Aguilar, G. M. L.; O'Reilly, K.; Alvarez, P. J. J. A comparison of benzene and toluene plume lengths for sites contaminated with regular vs.

Environmental Science \& Technology, Vol 42, No. 7 (2008): pg. 2289-2294. DOI. This article is (C) American Chemical Society and permission has been granted for this version to appear in e-Publications@Marquette. American Chemical Society does not grant permission for this article to be further copied/distributed or hosted elsewhere without the express permission from American Chemical Society. 
NOT THE PUBLISHED VERSION; this is the author's final, peer-reviewed manuscript. The published version may be accessed by following the link in the citation at the bottom of the page.

Ethanol-amended gasoline Ground Wat. Monitor. Remed. 200223148 53

${ }^{10}$ Mackay, D.; de Sieyes, N.; Einarson, M.; Feris, K.; Pappas, A.; Wood, I.; Jacobson, L.; Justice, L.; Noske, M.; Wilson, J.; Adair, C.; Scow, K. Impact of ethanol on the natural attenuation of MTBE in a normally sulfate-reducing aquifer Environ. Sci. Technol. 200741620152021

${ }^{11}$ Wilson, R. D.; MacKay, D. M.; Scow, K. M. In situ MTBE biodegradation supported by diffusive oxygen release Environ. Sci. Technol. 200236 190199

${ }^{12}$ McElvie, J.; Mackay, D.; de Sieyes, N.; Lacrampe-Couloume, G.; Sherwood Lollar, B. Quantifying MTBE biodegradation in the Vandenberg Air Force Base ethanol release study using stable carbon isotopes $J$. Contamin. Hydrol. 200794157165

${ }^{13}$ Hristova, K.; Gebreyesus, B.; Mackay, D.; Scow, K. M. Naturally occurring bacteria similar to the methyl tert-butyl ether (MTBE)-degrading strain PM1 are present in MTBE-contaminated groundwater Appl. Environ. Microbiol. 200369526162623

${ }^{14}$ Einarson, M. D.; Schirmer, M.; Pexeshkpour, P.; Mackay, D. M.; Wilson, R. D. In Comparison of Eight Innovative Site Characterization Tools Used to Investigate an MTBE Plume at Site 60, Vandenberge Air Force Base, California, 1999 Petroleum Hydrocarbons Conference, Houston, Texas, 1999; National Ground Water Association \& American Petroleum Institute: Houston, Texas, 1999.

${ }^{15}$ Nass, C.; Wilson, R. D.; MacKay, D. M.; Scow, K. M. Investigation of spatial distribution of native aerobic MTBE-degrading microorganisms: Preliminary results. Contamin. Soil, Sed., and Wat., July (Special issue), 2002.

${ }^{16}$ Mackay, D. M.; Wilson, R. D.; Scow, K. M.; Einarson, M. D.; Fowler, B. A.; Wood, I. In situ remediation of MTBE at Vandenberg Air Force Base, California Contaminated Soil Sediment and Water. 2001 AEHS Spring Special Issue 4346

${ }^{17}$ Feris, K. P.; Ramsey, P. W.; Frazar, C. F.; Rillig, M. C.; Gannon, J. E.; Holben, W. E. Structure and seasonal dynamics of hyporheic zone microbial communities in free-stone rivers of the western United States Microb. Ecol. 2003462200215

${ }^{18}$ Suzuki, M. T.; Taylor, L. T.; DeLong, E. F. Quantitative analysis of smallsubunit rrna genes in mixed microbial populations via $5^{\prime}$-nuclease assays Appl. Environ. Microbiol. 2000661146054614

${ }^{19}$ Takai, K.; Horikoshi, K. Rapid detection and quantification of members of the archaeal community by quantitative PCR using fluorogenic probes Appl. Environ. Microbiol. $200066115066+$

${ }^{20}$ Anderson, R. T.; Vrionis, H. A.; Ortiz-Bernad, I.; Resch, C. T.; Long, P. E.; Dayvault, R.; Karp, K.; Marutzky, S.; Metzler, D. R.; Peacock, A.; 
NOT THE PUBLISHED VERSION; this is the author's final, peer-reviewed manuscript. The published version may be accessed by following the link in the citation at the bottom of the page.

White, D. C.; Lowe, M.; Lovley, D. R. Stimulating the in situ activity of geobacter species to remove uranium from the groundwater of a uranium-contaminated aquifer Appl. Environ. Microbiol. 20036910 58845891

${ }^{21}$ Townsend, T. G.; Prince, R. C.; Suflita, J. M. Anaerobic oxidation of crude oil hydrocarbons by the resident microorganisms of a contaminated anoxic aquifer Environ. Sci. Technol. 2003372252135218

${ }^{22}$ Dojka, M. A.; Hugenholtz, P.; Haack, S. K.; Pace, N. R. Microbial diversity in a hydrocarbon- and chlorinated-solvent-contaminated aquifer undergoing intrinsic bioremediation Appl. Environ. Microbiol. 199864 1038693877

${ }^{23}$ Reinhard, M.; Hopkins, G. D.; Steinle-Darling, E.; LeBron, C. A. In situ biotransformation of BTEX compounds under methanogenic conditions Ground Water Monitor. and Remed. 20052545059

${ }^{24}$ Da Silva, M. L. B.; Ruiz-Aguilar, G. M. L.; Alvarez, P. J. J. Enhanced anaerobic biodegradation of BTEX-ethanol mixtures in aquifer columns amended with sulfate, chelated ferric iron or nitrate Biodegrad. 2005 162105114

${ }^{25}$ Somsamak, P.; Richnow, H. H.; Haggblom, M. M. Carbon isotope fractionation during anaerobic degradation of methyl tert-butyl ether under sulfate-reducing and methanogenic conditions Appl. Environ. Microbiol. 200672211571163

${ }^{26} \mathrm{Falta}, \mathrm{R}$. W. The potential for ground water contamination by the gasoline lead scavengers ethylene dibromide and 1,2-dichloroethane Ground Water Monitor. and Remed. 20042437687

Environmental Science \& Technology, Vol 42, No. 7 (2008): pg. 2289-2294. DOI. This article is (C) American Chemical Society and permission has been granted for this version to appear in e-Publications@Marquette. American Chemical Society does not grant permission for this article to be further copied/distributed or hosted elsewhere without the express permission from American Chemical Society. 